\title{
Isolation screening and molecular characterization of zinc solubilizing bacteria and their effect on the growth of wheat (Triticum aestivum)
}

\author{
Vandana Nandal, Manu Solanki* \\ Manav Rachna International Institute of Research and Studies, Department of Biotecbnology, 121004 Faridabad, Haryana, India
}

Received 13th February 2021 / Accepted 11th May 2021

\begin{abstract}
Wheat (Triticum aestivum) is a major cereal crop grown worldwide. Most of the world population depends on wheat for their nutrient requirement. Zinc $(\mathrm{Zn})$ is one of the most crucial elements required for the development of wheat plant. It is one of the micronutrients required in many biochemical cycles. It has been found that the concentration of $\mathrm{Zn}$ is below the required level in the soil and hence it remains deficient in the crops. To ameliorate the deficit, chemical fertilizers are added in the soil, where as biofertilizers are preferred over chemicals in sustainable agriculture. The paper describes the isolation, screening and molecular characterization of the zinc solubilizing bacteria (ZSB) to improve plant growth. A total of 100 soil samples were collected from the rhizospheric soil of wheat plants. ZSB were isolated by dilution plating on Bunt and Rovira media. The 50 isolates were selected and screened for their $\mathrm{Zn}$ solubilization. The zinc tolerance of all the isolates varied from $0.5 \%$ to $2 \%$ of insoluble $\mathrm{Zn}$. Based on the $\mathrm{Zn}$ tolerance ability, 15 bacterial isolates were screened for Phosphate solubilization and further analyzed for the synthesis of IAA, $\mathrm{NH}_{3}$, siderophore production and chitinase activity. The three isolates were selected on the basis of the plant growth promoting characteristics for molecular characterization and were found to be homologous to Bacillus cereus, Pseudomonas aeruginosa and Bacillus tropicus. This study documented the establishment and survival of ZSB in the wheat rhizosphere and enhanced plant productivity, thus indicating the potential of isolates as commercial biofertilizers.
\end{abstract}

Keywords: Rhizosphere, wheat, Zn, zinc solubilising bacteria (ZSB)

\section{INTRODUCTION}

Worldwide nutrient deficiency is a major concern affecting plants as well as humans. Nutrients are classified into two groups as micro and macronutrients. Sodium, potassium, phosphorus, calcium, magnesium and sodium are characterized as macronutrients as they are present in abundance, while iron, manganese, copper, zinc, boron and molybdenum are required by plants in minute quantities, therefore, they are called trace elements or micronutrients (Sharma et al., 2013).
Malnutrition due to trace elements is an issue that needs to be addressed globally (Roohani et al., 2013). Zn deficiency is an emerging challenge seen in humans which directly or indirectly is dependent upon the $\mathrm{Zn}$ status of the crops (Noulas et al., 2018).

$\mathrm{Zn}$ is the most ubiquitous nutrient requisite of most plant enzymes. There are approximately 3000 protein $\mathrm{Zn}$ prosthetic groups in humans and animals (Alloway, 2009). $\mathrm{Zn}$ is a catalytic

*Author for correspondence: Manu Solanki, Manav Rachna International Institute of Research and Studies, Department of Biotechnology, 121004 Faridabad, Haryana, India. Email - solankimanu.fet@mriu.edu.in; manutsolanki@gmail.com 
component of several enzymes and is crucial for their activity. In plants $\mathrm{Zn}$ deficiency leads to impeded photosynthesis, metabolism of nitrogen, carbohydrate synthesis, delayed growth of flowers and fruits and additionally detains maturity in crops thus eventually affecting the yield and nutrient quality (Cele and Maboeta, 2016).

Like several other developing nations, India also faces a challenge, and it is estimated that around $50 \%$ of Indian semi-arid soil is $\mathrm{Zn}$ deficient (Malik et al., 2017). Soils mainly contain a large concentration of total $\mathrm{Zn}$ that occur in the inactive forms in minerals like franklinite $\left(\mathrm{ZnFe}_{2} \mathrm{O}_{4}\right)$, hopeite $\mathrm{Zn}_{3}\left(\mathrm{PO}_{4}\right)_{2}$, sphalerite $(\mathrm{ZnS})$, smithsonite $\left(\mathrm{ZnCO}_{3}\right)$, Znite $(\mathrm{ZnO})$, willemite $\left(\mathrm{Zn} 2 \mathrm{SiO}_{4}\right)($ Broadley et al., 2007). The critical value of $\mathrm{Zn}$ in the soil varies from 0.6 to $1.2 \mathrm{ppm}$ or $\mathrm{mg} / \mathrm{kg}$ of soil; less than $0.6 \mathrm{ppm}$ means the soil is $\mathrm{Zn}$ deficient, and above $1.2 \mathrm{ppm}$ indicates $\mathrm{Zn}$ toxicity. Whereas in the plants the concentration of $\mathrm{Zn}$ could reach $20-300$ ppm, only a minute level is in readily available form as the solubility of $\mathrm{Zn}$ is very low in the soil as compared to other nutrients. The solubility of $\mathrm{Zn}$ is affected by the $\mathrm{pH}$ and moisture content of soil (Athokpam et al., 2018).

There are various strategies to counteract the deficiency of $\mathrm{Zn}$ which includes biofortification and agronomic practices (Vejan et al., 2016). The application of $\mathrm{Zn}$ fertilizers is also one of the practices used to overcome $\mathrm{Zn}$ deficiency in $\mathrm{Zn}$ deficient soil. Even though they seem fast and easy to process, the cost of fertilizers are exorbitant (Hafeez et al., 2013). Moreover, the applied $\mathrm{Zn}$ gets transmuted into various inactive forms based on the types of soil and physicochemical composition of soils (Vidyashree et al., 2016). The use of microorganisms is a prospective alternate strategy used in this respect (Abaid Ullah et al., 2015). Plant growth-promoting rhizobacteria (PGPR) are registered for their potential to solubilise inactive forms of $\mathrm{Zn}$ and thus air crop yield (Goteti et al., 2013). Zn solubilising bacteria belongs to the category of PGPR consisting of numerous beneficial bacteria that reside in the rhizosphere of plants (Prasad et al., 2015). ZSB assists in the growth and development of plants via stimulating biochemical processes like atmospheric nitrogen fixation and synthesizing siderophores (El-Sayed et al., 2014). Siderophores can link with $\mathrm{Zn}$ to form a complex and make $\mathrm{Zn}$ available for plant uptake. These bacteria convert insoluble $\mathrm{Zn}$ into a soluble form in various ways like the production of organic acids, siderophores, ammonia and mineral acids resulting in acidification of surrounding soil which also solubilises insoluble $\mathrm{Zn}$ chelates (Kamran et al., 2017). Another mechanism through which PGPR enhances the growth of plants is due to the production of Exopolysaccharide (EPS). EPS is high molecular weight and biodegradable polymer which comprises a vital part of the organic matter of the soil. EPS aids in sustaining soil aggregation, water potential and keeping stress condition under control (Gouda et al., 2018). EPS producing bacteria are capable of balancing the drought-like situation and promote growth (Upadhyay et al., 2011). Considering the necessity of the desired amount of $\mathrm{Zn}$ in the plants and its available status in the soil, this study was carried out to isolate, screen and study the establishment of potential $\mathrm{Zn}$ solubilizing bacteria in the rhizosphere of the wheat.

\section{MATERIALS AND METHODS}

\section{Collection of thizospheric soil samples}

Samples of soil were collected from rhizosphere of wheat from the different regions of district Faridabad, Haryana. In the Faridabad region wheat is one of the major crops. The uprooting of plants is done in a sterilized manner and the narrow region of soil surrounding the roots of the plant called rhizospheric soil is collected by vigorous shaking in sterilized Ziplock bags. Post collection, soil samples were transferred to the lab where they were dried to remove excess moisture and stored at $4^{\circ} \mathrm{C}$ for further analysis.

\section{Isolation of $Z S B$}

ZSB were isolated from the stored soil samples using serial dilution plating on Bunt and Rovira (B\&R) medium. The composition was ( $\mathrm{g} / \mathrm{l})$ : glucose $(20 \mathrm{~g})$, peptone $(1 \mathrm{~g}), \mathrm{NH}_{4} \mathrm{SO}_{4}(0.5 \mathrm{~g}), \mathrm{K}_{2}$ $\mathrm{HPO}_{4}(0.4 \mathrm{~g})$, Yeast extract (1g), $\mathrm{FeCl}_{4}(0.01 \mathrm{~g})$, $\mathrm{MgCL}_{2}(0.1 \mathrm{~g})$, agar (2\%), $\mathrm{ZnO}(0.1 \%)$ (AbaidUllah et al., 2015). The rhizospheric soil samples were diluted up to the $10^{-7}$ dilution in the sterile water blanks, and the last three dilutions were 
spreaded on Bunt \& Rovira media. The incubation was done for 2 days at $30 \pm 2^{\circ} \mathrm{C}$. Colonies around which a halo zone appeared were considered as $\mathrm{Zn}$ solubilising bacteria and these zone forming isolates were again streaked for purification before transferring them on Bunt \& Rovira slants for further experimentation.

\section{Zn solubilising assay}

The selected bacterial isolates were inoculated on Bunt \& Rovira media containing $0.1 \% \mathrm{ZnO}$ to determine $\mathrm{Zn}$ solubilisation and incubated at $30^{\circ} \mathrm{C}$ for 48 hours (Abaid-Ullah et al., 2015). The halo zone diameter and colony zone diameter were estimated using a measuring scale. Zinc solubilization efficiency (ZSE) was estimated as:

$\mathrm{ZSE}=$ (Halozone diameter - colony diameter)/diameter of colony X 100 (Khanghahi et al., 2018).

\section{Screening for Zn tolerance}

$\mathrm{Zn}$ becomes toxic to plants as well as to microbes when it is present in higher concentration in the soil. As the concentration of $\mathrm{Zn}$ increases, it retards bacterial growth. If the bacteria cannot tolerate higher concentration of $\mathrm{Zn}$, they are unable to solubilize it. Hence $\mathrm{Zn}$ tolerance of isolates was determined on Bunt \& Rovira media at different concentrations of zinc oxide $(0.5 \%$, $1 \%, 1.5 \%$ and $2 \%$ ). If the bacteria continue to grow at higher concentrations it is considered tolerant to $\mathrm{Zn}$. At the same time if the halo zone is observed around the colonies it indicates that the bacteria are capable of $\mathrm{Zn}$ solubilization as well. The concentration at which the bacteria were unable to form colony was considered as its $\mathrm{Zn}$ tolerance value or minimal inhibitory concentration(MIC) of Zn (Sarvana et al., 2004).

\section{Phosphate solubilization efficiency}

Phosphate solubilisation of bacterial isolates was determined by inoculating the isolates on Pikovskaya's Medium (PVK) having the composition: glucose $(10 \mathrm{~g}), \mathrm{KCl}(0.2 \mathrm{~g}), \mathrm{MgCl}_{2}$ (0.1 g), $\mathrm{NH}_{4} \mathrm{SO}_{4}(0.2 \mathrm{~g}), \mathrm{NaCl}(0.2 \mathrm{~g}), \mathrm{FeSO}_{4}(0.02$ $\mathrm{g}), \mathrm{MgSO}_{4}(0.2 \mathrm{~g})$ Yeast extract $(0.5 \mathrm{~g})$, Tricalcium phosphate $(0.02 \mathrm{~g})$, distilled water $1000 \mathrm{ml}$. The $\mathrm{pH}$ was adjusted to 7 . The plates were then incubated for $48 \mathrm{~h}$ at $30 \pm 2^{\circ} \mathrm{C}$. The colonies that formed clear halo zone were noted as phosphate solubilizers (Pande et al., 2017). Phosphate solubilization efficiency is estimated as:

PSE $=$ (Halozone diameter - colony diameter)/diameter of colony X 100.

\section{Siderophores production}

The siderophore production assay was performed by Chrome azurol S (CAS) reagent $(121 \mathrm{mg}$ of chromeazurol-S added to $100 \mathrm{ml}$ distilled water and $20 \mathrm{ml}$ of $1 \mathrm{mM}\left(\mathrm{FeCl}_{3} \cdot 6 \mathrm{H}_{2} \mathrm{O}\right)$ ferric chloride solution mixed with $10 \mathrm{mM} \mathrm{HCl}$ ). To this mixture $20 \mathrm{ml}$ of $1.8 \mathrm{~g} / 1$ Hexadecyl trimethyl ammonium bromide (HDTMA) solution was added. CAS plates were made using CAS reagent and LB agar. An aliquot of the selected bacterial isolates containing approximately $10^{8} \mathrm{cfu} / \mathrm{ml}$ was inoculated and incubated for 7 days at $28^{\circ} \mathrm{C}$ to check for production of orange halo zone(Arora and Verma, 2017).

\section{Indole acetic acid production}

Production of auxin was evaluated using lab assay (Agbodjato et al., 2018). Around $3 \mathrm{ml}$ of bacterial culture is mixed with $2 \mathrm{ml}$ of Salkowski reagent consisting of $2 \mathrm{ml}$ of $0.5 \mathrm{M} \mathrm{FeCl}_{3}$ and $98 \mathrm{ml}$ of $35 \% \mathrm{HClO}_{4}$. The mixture was kept at room temp for 30 minutes to develop a pink to dark red colour. The intensity of the colour developed is quantified at $500 \mathrm{~nm}$ after the slight colour change was noticed by using a spectrophotometer (Mohite, 2013).

\section{Ammonium production}

Isolates were inoculated in $10 \mathrm{ml}$ of peptone broth and incubated at $30^{\circ} \mathrm{C}$ for a period of $48 \mathrm{~h}$. After the incubation, $0.5 \mathrm{ml}$ of Nessler's reagent was added into the tube. The appearance of light yellow to brown colour was considered as positive for ammonia production (Mumtaz et al., 2017).

\section{Exopolysaccharide production}

Exopolysaccharide (EPS) production was tested by inoculating the bacterial isolates on RCV sucrose media containing $0.1 \mathrm{~g}$ yeast extract, $15 \mathrm{~g}$ agar and $30 \mathrm{~g}$ sucrose in $100 \mathrm{ml}$ distilled water. The culture was incubated for 4 days at $30^{\circ} \mathrm{C}$. The EPS production was characterized as having slimy appearance along with mucoid growth (Yadav et al., 2018). 


\section{Chitinase activity}

Chitinase activity in bacterial isolates was determined by growing bacterial cultures on colloidal chitin agar consisting of $10 \mathrm{~g}$ colloidal chitin, $0.5 \mathrm{~g} \mathrm{~K}_{2} \mathrm{HPO}_{4}$, $0.5 \mathrm{~g} \mathrm{MgSO}_{4} .7 \mathrm{H}_{2} \mathrm{O}, 0.5 \mathrm{~g}$ $\mathrm{Na}_{2} \mathrm{HPO}_{4}, 3.0 \mathrm{~g} \mathrm{NaNO}$, $1 \mathrm{~g}$ Yeast extract. Total volume was made to $1000 \mathrm{ml}$ by distilled water and pH adjusted to 7 after adding agar@2\%. An aliquot of the isolates containing approximately $10^{8} \mathrm{cfu} / \mathrm{ml}$ was spotted on the plates and incubated at $30^{\circ} \mathrm{C}$ for 7 days. Chitinase activity was characterized by the halo zones formed around bacterial colonies (Moustaine et al., 2017).

\section{Nitrogen fixation}

The screening for nitrogen fixation was done by growing bacterial isolates on solid nitrogen - free malate medium consisting of $6.0 \mathrm{~g} \mathrm{~K}_{2} \mathrm{HPO}_{4}, 0.02$

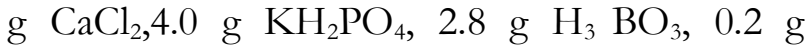
$\mathrm{MgSO}_{4} .7 \mathrm{H}_{2} \mathrm{O}, 3.0 \mathrm{~g} \mathrm{NaOH}, 1.0 \mathrm{~g} \mathrm{NH} \mathrm{Nl}_{4}, 0.1 \mathrm{~g}$ $\mathrm{NaCl}, 0.01 \mathrm{~g} \mathrm{FeCl}_{3}, 5.0 \mathrm{~g}$ DL-malic acid, $0.02 \mathrm{~g}$ $\mathrm{NaMoO}_{4} \cdot 2 \mathrm{H}_{2} \mathrm{O}, \quad 0.002 \mathrm{~g} \quad \mathrm{MnSO}_{4}, \quad 0.04 \mathrm{mg}$ $\mathrm{Cu}\left(\mathrm{NO}_{3}\right)_{2} .3 \mathrm{H}_{2} \mathrm{O}, 0.24 \mathrm{mg} \mathrm{ZnSO}{ }_{4} .7 \mathrm{H}_{2} \mathrm{O}$ per 1000 $\mathrm{ml}$ of distilled water. The $\mathrm{pH}$ was adjusted to 7 and isolates are incubated at $32^{\circ} \mathrm{C}$ for $24 \mathrm{~h}$. The nitrogen fixation was characterized by the change of colour of media from pale green to blue. Blue colour Zone producing bacteria were characterized as nitrogen fixers (Kuan et al., 2016).

\section{Pot experiment to determine crop response and establishment of ZSB in wheat rhizosphere}

The selected ZSB isolates were checked for the crop response and their establishment in the rhizosphere of wheat. Seeds were inoculated with the culture broth of the selected isolates containing approximately $10^{6}$ cells $/ \mathrm{ml}$ for 30 minutes. The pot experiment was carried out in pots made of plastics which were filled with sterilized soil (4 kg). (Khan and Bano, 2019). The soil that was used for this experiment was sandy loam, pH 7.8, E.C. $-0.182 \mathrm{dS} / \mathrm{m}$, nitrogen -0.040 , $\%$ organic carbon- $-0.12 \%$ and total phosphorus $8.0 \mathrm{~kg} / \mathrm{ha}$. Wheat seeds coated with bacterial isolates (ZA1, ZI4, ZJ3, ZK41, ZL25, ZM9 and ZT19) were sown along with control (uninoculated). Ten seeds were sown/pot which was later thinned to 5 . $\mathrm{Zn}$ oxide and $\mathrm{Zn}$ sulphate were taken as a source of $\mathrm{Zn}$. The experiment was performed with these treatments in the triplicates: control, $5 \mathrm{ppm} \mathrm{Zn}$ as $\mathrm{ZnO}+$ culture, $10 \mathrm{ppm} \mathrm{Zn}$ as $\mathrm{ZnO}+$ culture, $5 \mathrm{ppm} \mathrm{Zn}$ as $\mathrm{ZnSO}_{4}+$ culture and $10 \mathrm{ppm} \mathrm{Zn}$ as $\mathrm{ZnSO}_{4}+$ culture. Pots were watered manually once every 2-3 days till 90 days. Plants were cautiously uprooted after 30,60 , and 90 days of sowing (DAS) from the plastic pots. The rhizospheric soil was taken from every pot, $5 \mathrm{gm}$ of soil is dissolved in $45 \mathrm{ml}$ of sterilized water and dilutions were prepared up to $10^{-6}$ and the last three dilutions were streaked on Bunt \& Rovira media plates. After incubation for $48 \mathrm{~h}$ at $30 \pm 2^{\circ} \mathrm{C}$, bacterial colonies showing halo zone around them were taken as $\mathrm{Zn}$ solubilizers and were counted. The average of three plates (cfu/g of soil) was considered the final value (Khanghahi et al., 2018).

\section{Determination of shoot biomass}

The plants were uprooted from all the treatments at 30,60, and 90 days after sowing (DAS) and dried in oven at $80^{\circ} \mathrm{C}$ to a constant shoot weight. The shoot biomass of the plants from all the treatments was calculated. The results are analysed using SPSS software of data analysis (Kamran et al., 2017).

\section{$16 S \mathrm{rRNA}$ gene sequencing}

To determine the phylogenetic relationships, genomic DNA was isolated using the CTAB method (Kumar et al., 2016). Quality of genome was evaluated on $1.0 \%$ agarose gel. $27 \mathrm{~F}$ and 1492R universal primers were used to amplify fragments of 16SrDNA. The PCR amplicon was purified to remove contaminants. Forward and reverse DNA sequencing reaction of PCR amplicon was carried out with forwarding primer and reverse primers using BDT v3.1 Cycle sequencing kit on ABI 3730xl Genetic Analyzer. A consensus sequence of the $16 \mathrm{~S}$ rDNA gene was generated from forward and reverse sequence data using aligner software. The $16 \mathrm{~S}$ rDNA gene sequence was used to carry out BLAST with the database of NCBI Genbank database. Based on the maximum identity score first ten sequences were selected and aligned using multiple alignment software program Clustal W. Distance matrix was generated and MEGA 7 is used to generate a phylogenetic tree. The Maximum Likelihood method is used to infer evolutionary history. The bootstrap consensus tree was used for representing evolutionary history. The Gene sequence of the bacterial isolates was analysed at 
NCBI GenBank using the BLAST programme and a phylogenetic tree was constructed (Kumar et al., 2016).

\section{RESULTS}

\section{Screening of bacterial isolates and ZSE determination}

The current study was conducted with the aim to isolate and characterize $\mathrm{Zn}$ solubilizing bacterial isolates from the rhizosphere of wheat crops in soils of Haryana, India. Their potential to solubilize inorganic forms of $\mathrm{Zn}$ is determined. A total of 50 isolates were purified and named as depicted in Table 1. Eight out of these 50 isolates showed strong solubilisation of inorganic $\mathrm{Zn}$. The isolates showing strong solubilisation were ZA1, ZI4, ZJ3, ZK7, ZM15, ZW22, ZB37, and ZK41. The halo zone diameter of the isolates ranged from $0.8 \mathrm{~cm}$ to $2.75 \mathrm{~cm}$. ZSB strains ZA1, ZJ3 and $\mathrm{K} 41$ displayed maximum halo zone diameter, while least solubilisation efficiency was observed in ZW49 and ZM32. The most efficient isolates with respect to ZSE were ZA1 and ZK41.

Table 1. Colony diameter, $\mathrm{Zn}$ halozone diameter, $\mathrm{Zn}$ solubilising efficacy, and minimal inhibitory concentration of rhizospheric bacterial isolates on B \& R media.

\begin{tabular}{|c|c|c|c|c|c|}
\hline Isolates & $\begin{array}{c}\text { Colony } \\
\text { diameter } \\
(\mathrm{cm})\end{array}$ & $\begin{array}{l}\text { Zn halozone } \\
\text { diameter }(\mathrm{cm})\end{array}$ & ZSE (\%) & $\begin{array}{c}\text { MIC } \\
(\% \text { of } \mathrm{ZnO})\end{array}$ & $\mathrm{pH}$ \\
\hline ZA1 & $0.393 \pm 0.012$ & $2.367 \pm 0.058$ & $508.667 \pm 15.011$ & 2 & $3.633 \pm 0.379$ \\
\hline $\mathrm{ZJ} 2$ & $0.483 \pm 0.029$ & $1.717 \pm 0.058$ & $255.333 \pm 9.238$ & 2 & $5.067 \pm 0.839$ \\
\hline ZJ3 & $0.407 \pm 0.012$ & $2.417 \pm 0.029$ & $494.333 \pm 9.815$ & 2 & $3.300 \pm 0.100$ \\
\hline ZI4 & $0.0597 \pm 0.006$ & $2.417 \pm 0.029$ & $305.000 \pm 8.660$ & 2 & $4.333 \pm 0.321$ \\
\hline ZK5 & $0.390 \pm 0.017$ & $2.067 \pm 0.058$ & $430.000 \pm 8.660$ & 2 & $3.540 \pm 0.461$ \\
\hline ZK6 & $0.967 \pm 0.058$ & $2.200 \pm 0.100$ & $128.333 \pm 23.629$ & 1.5 & $5.247 \pm 0.344$ \\
\hline ZK7 & $0.397 \pm 0.006$ & $1.767 \pm 0.058$ & $345.000 \pm 8.660$ & 2 & $3.967 \pm 0.115$ \\
\hline ZK8 & $0.683 \pm 0.029$ & $2.500 \pm 0.100$ & $265.667 \pm 7.572$ & 1.5 & $5.130 \pm 0.256$ \\
\hline ZM9 & $0.683 \pm 0.029$ & $2.300 \pm 0.000$ & $244.333 \pm 7.506$ & 1 & $5.127 \pm 0.329$ \\
\hline ZM10 & $0.683 \pm 0.029$ & $1.467 \pm 0.029$ & $118.333 \pm 9.866$ & 1.5 & $5.900 \pm 0.200$ \\
\hline ZM11 & $0.893 \pm 0.012$ & $1.467 \pm 0.029$ & $66.667 \pm 7.371$ & 2 & $6.750 \pm 0.229$ \\
\hline ZM12 & $0.697 \pm 0.006$ & $1.267 \pm 0.012$ & $78.667 \pm 1.528$ & 2 & $6.420 \pm 0.381$ \\
\hline ZM13 & $0.867 \pm 0.058$ & $1.950 \pm 0.044$ & $128.000 \pm 15.602$ & 1.5 & $5.790 \pm 0.271$ \\
\hline ZM14 & $0.593 \pm 0.012$ & $1.183 \pm 0.029$ & $116.000 \pm 15.588$ & 1 & $6.600 \pm 0.173$ \\
\hline ZM15 & $0.593 \pm 0.012$ & $2.400 \pm 0.000$ & $304.333 \pm 7.506$ & 2 & $4.300 \pm 0.436$ \\
\hline ZM16 & $0.493 \pm 0.012$ & $1.000 \pm 0.000$ & $104.333 \pm 7.506$ & 2 & $5.733 \pm 0.208$ \\
\hline ZO17 & $0.693 \pm 0.012$ & $1.400 \pm 0.050$ & $101.667 \pm 10.599$ & 2 & $5.540 \pm 0.393$ \\
\hline ZS18 & $0.393 \pm 0.012$ & $0.877 \pm 0.006$ & $125.667 \pm 4.933$ & 2 & $5.833 \pm 0.208$ \\
\hline ZT19 & $0.593 \pm 0.012$ & $1.793 \pm 0.012$ & $201.333 \pm 4.163$ & 2 & $5.267 \pm 0.289$ \\
\hline ZW20 & $0.817 \pm 0.029$ & $1.363 \pm 0.006$ & $70.333 \pm 0.577$ & 2 & $6.420 \pm 0.509$ \\
\hline ZW21 & $1.000 \pm 0.000$ & $2.653 \pm 0.006$ & $165.333 \pm 0.577$ & 2 & $6.100 \pm 0.200$ \\
\hline ZW22 & $0.400 \pm 0.000$ & $1.900 \pm 0.100$ & $375.000 \pm 25.000$ & 2 & $3.867 \pm 0.058$ \\
\hline ZW23 & $0.794 \pm 0.012$ & $1.707 \pm 0.012$ & $115.667 \pm 4.041$ & 1.5 & $5.883 \pm 0.225$ \\
\hline ZW24 & $0.693 \pm 0.029$ & $2.133 \pm 0.058$ & $212.667 \pm 21.939$ & 2 & $5.400 \pm 0.361$ \\
\hline ZL25 & $0.493 \pm 0.006$ & $2.000 \pm 0.000$ & $302.667 \pm 4.619$ & 2 & $4.467 \pm 0.451$ \\
\hline ZR26 & $1.167 \pm 0.058$ & $2.167 \pm 0.058$ & $85.333 \pm 4.041$ & 2 & $6.233 \pm 0.115$ \\
\hline ZM27 & $0.967 \pm 0.058$ & $2.167 \pm 0.058$ & $120.000 \pm 0.000$ & 2 & $5.600 \pm 0.173$ \\
\hline ZB28 & $0.967 \pm 0.058$ & $1.667 \pm 0.029$ & $72.667 \pm 9.292$ & 1 & $6.570 \pm 0.517$ \\
\hline ZC29 & $0.667 \pm 0.058$ & $1.683 \pm 0.029$ & $125.000 \pm 43.301$ & 2 & $6.093 \pm 0.040$ \\
\hline ZM30 & $0.967 \pm 0.058$ & $1.683 \pm 0.058$ & $69.333 \pm 16.166$ & 1.5 & $6.023 \pm 0.741$ \\
\hline ZC31 & $0.967 \pm 0.058$ & $1.667 \pm 0.058$ & $72.333 \pm 4.041$ & 2 & $6.023 \pm 0.503$ \\
\hline
\end{tabular}




\begin{tabular}{cccccc}
\hline ZM32 & $0.967 \pm 0.058$ & $1.500 \pm 0.000$ & $55.333 \pm 9.238$ & 2 & $6.467 \pm 0.379$ \\
\hline ZC33 & $0.667 \pm 0.058$ & $2.500 \pm 0.100$ & $271.333 \pm 29.000$ & 2 & $6.433 \pm 0.229$ \\
\hline ZS34 & $1.000 \pm 0.000$ & $2.300 \pm 0.100$ & $130.000 \pm 10.000$ & 2 & $4.650 \pm 0.336$ \\
\hline ZC35 & $0.967 \pm 0.058$ & $2.233 \pm 0.058$ & $131.333 \pm 12.055$ & 1.5 & $5.737 \pm 0.284$ \\
\hline ZC36 & $0.500 \pm 0.000$ & $1.967 \pm 0.058$ & $292.333 \pm 11.547$ & 1.5 & $5.583 \pm 0.451$ \\
\hline ZB37 & $0.500 \pm 0.000$ & $2.167 \pm 0.058$ & $333.333 \pm 11.547$ & 1.5 & $4.133 \pm 0.208$ \\
\hline ZK38 & $0.933 \pm 0.058$ & $2.000 \pm 0.000$ & $114.667 \pm 12.702$ & 1.5 & $4.333 \pm 0.416$ \\
\hline ZM39 & $0.680 \pm 0.017$ & $1.533 \pm 0.058$ & $123.667 \pm 14.012$ & 1.5 & $5.567 \pm 0.252$ \\
\hline ZJ40 & $0.497 \pm 0.006$ & $1.600 \pm 0.100$ & $222.000 \pm 23.065$ & 1.5 & $5.467 \pm 0.231$ \\
\hline ZK41 & $0.497 \pm 0.006$ & $2.750 \pm 0.000$ & $453.667 \pm 6.351$ & 2 & $3.767 \pm 0.152$ \\
\hline ZJ42 & $0.700 \pm 0.000$ & $2.483 \pm 0.029$ & $254.667 \pm 4.041$ & 1.5 & $4.567 \pm 0.404$ \\
\hline ZC43 & $1.167 \pm 0.058$ & $2.167 \pm 0.058$ & $88.667 \pm 9.815$ & 2 & $6.133 \pm 0.551$ \\
\hline ZC44 & $0.967 \pm 0.058$ & $1.693 \pm 0.012$ & $75.333 \pm 9.238$ & 2 & $6.433 \pm 0.510$ \\
\hline ZC45 & $1.000 \pm 0.000$ & $1.693 \pm 0.012$ & $69.333 \pm 1.155$ & 1.5 & $6.583 \pm 0.401$ \\
\hline ZF46 & $1.000 \pm 0.000$ & $1.933 \pm 0.058$ & $93.333 \pm 5.774$ & 1.5 & $6.033 \pm 0.223$ \\
\hline ZW47 & $0.967 \pm 0.058$ & $2.967 \pm 0.058$ & $207.333 \pm 12.702$ & 2 & $4.667 \pm 0.252$ \\
\hline ZK48 & $0.683 \pm 0.029$ & $2.493 \pm 0.006$ & $265.000 \pm 15.620$ & 2 & $4.667 \pm 0.153$ \\
\hline ZW49 & $0.933 \pm 0.058$ & $1.497 \pm 0.006$ & $55.000 \pm 9.539$ & 2 & $6.640 \pm 0.539$ \\
\hline ZC50 & $0.933 \pm 0.058$ & $2.033 \pm 0.058$ & $118.333 \pm 16.803$ & 2 & $5.653 \pm 0.134$ \\
\hline CD at 5\% & 0.3674243 & 0.7457546 & 198.30672 & & 0.491429 \\
\hline
\end{tabular}

The data is the mean of 3 experiments. Critical difference (CD) is calculated at $5 \%$ significance level.

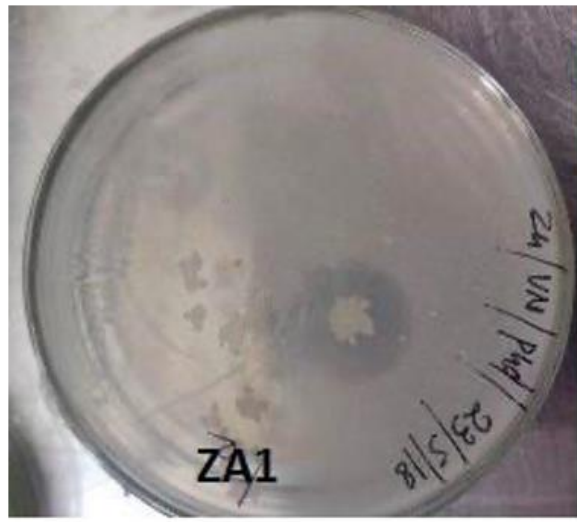

(a)

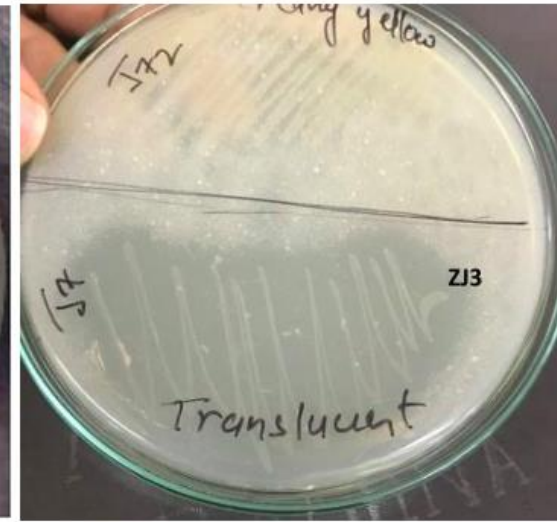

(b)

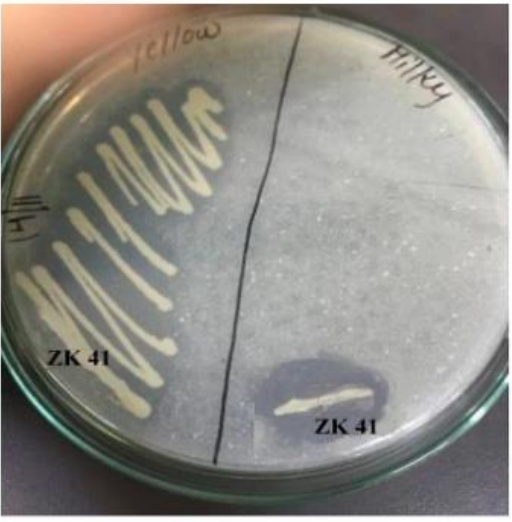

(c)

Figure 1. Zn Solubilisation by ZSB on Bunt \& Rovira medium containing $0.1 \% \mathrm{ZnO}$ (a) isolate ZA1, (b) isolate ZJ3, (c) isolate ZK14.

\section{Phosphate solubilisation efficiency}

Table 2 displays that all the 15 bacterial isolates have capability to solubilize phosphate. The phosphate solubilisation efficiency (PSE) of isolated bacterial strains in Pikovskaya media showed that isolates ZA1 (550\%), ZJ3 (517\%), and ZK41 (450\%) were efficient.

\section{Plant growth promoting attributes of the isolates}

The plant growth promoting attributes were assessed for the selected bacterial isolates. All the isolates displayed IAA and auxin production. The results of various assays such as siderophores production, ammonia production, chitinase activity, exo-polysaccharides (EPS) production are summarized in Table 3. Siderophore production was characterized by an orange halo zone which was displayed by all isolates except ZK7, ZK8 and ZB37. Similarly, EPS production characterized by having slimy appearance was present in all except ZK7, ZK8and ZC36.All the isolates were also checked for ammonia production and the isolates exhibiting a change of 
colour to a faint yellow and brown were considered positive for ammonia production. The iodide and mercury present in Nessler's reagent react with ammonia to produce brown coloured substance (Zhao et al., 2019). The isolates ZK7, ZK8, ZB37 and ZC36 did not display ammonia production while the rest were tested positive for the production of ammonia.

Table 2. Phosphate solubilizing efficiency of rhizospheric bacteria.

\begin{tabular}{ccc}
\hline Isolates & PSE (\%) & pH \\
\hline ZA1 & $550.667 \pm 40.017$ & $3.497 \pm 0.300$ \\
ZJ3 & $517.333 \pm 46.876$ & $3.553 \pm 0.446$ \\
ZI4 & $350.333 \pm 16.563$ & $4.347 \pm 0.050$ \\
ZK5 & $428.667 \pm 15.373$ & $3.327 \pm 0,112$ \\
ZK7 & $299.667 \pm 7.024$ & $5.273 \pm 0.318$ \\
ZK8 & $200.000 \pm 11.060$ & $6.202 \pm 0.093$ \\
ZM9 & $300.333 \pm 18.009$ & $5.293 \pm 0.107$ \\
ZM15 & $152.000 \pm 15.3950$ & $6.367 \pm 0.058$ \\
ZW22 & $300.667 \pm 10.066$ & $5.450 \pm 0.132$ \\
ZL25 & $302.000 \pm 13.856$ & $5.483 \pm 0.411$ \\
ZC36 & $230.000 \pm 7.053$ & $5.723 \pm 0.103$ \\
ZB37 & $330.667 \pm 20.033$ & $3.783 \pm 0.388$ \\
ZK41 & $450.000 \pm 20.207$ & $3.400 \pm 0.312$ \\
ZJ42 & $242.667 \pm 16.577$ & $4.404 \pm 0.356$ \\
ZK48 & $248.648 \pm 10.408$ & $4.807 \pm 0.121$ \\
CD at 5\% & 190.95254 & 1.755361 \\
\hline
\end{tabular}

The data is the mean of 3 experiments \pm standard deviation. Critical Difference (CD) is calculated at 5\% significance.

\section{Establishment of ZSB in thizosphere of wheat plant}

The nutrient broth was inoculated with approximately $10^{4} \mathrm{cfu} / \mathrm{ml}$ of selected 7 isolates and incubated for $24 \mathrm{~h}$. The seeds of wheat are soaked in the culture broth of the selected isolates for $30 \mathrm{~min}$. Bacterial load on the seeds was found in the range of $3.2-5.2 \times 10^{6} \mathrm{cfu} / \mathrm{seed}$. The count of ZSB was calculated after 30, 60, and 90 days of sowing .The rhizospheric soil was taken from every pot, dilutions were prepared up to $10^{-6}$ and last three dilutions were streaked on Bunt \& Rovira media plates to calculate the number of ZSB. The maximum count was found to be after 90 DAS in the rhizosphere of the wheat inoculated with ZK41 i.e. $3.2 \times 10^{5} \mathrm{cfu} / \mathrm{g}$ (Table 4).

\section{Effect of inoculation of ZSB on shoot biomass under pot conditions}

The inoculation of seeds with bacterial isolates for pot culture experiment displayed improvement in the shoot biomass of the wheat plant as compared to the control. The inoculation of ZSB showed significant difference as compared to control (Figure 7).The maximum shoot biomass was observed in case of wheat inoculated with ZJ3 and ZK41( Table 5).

Table 3. Plant growth promoting attributes of ZSB isolates.

\begin{tabular}{|c|c|c|c|c|c|}
\hline Isolates & IAA production & $\mathrm{NH}_{3}$ & EPS & Siderophores & Chitinase activity \\
\hline ZA1 & + & + & + & + & + \\
\hline ZJ3 & + & + & + & + & + \\
\hline ZI4 & + & + & + & + & + \\
\hline ZK5 & + & + & + & + & + \\
\hline $\mathrm{ZK} 7$ & + & - & - & - & - \\
\hline ZK8 & + & - & - & - & - \\
\hline ZM9 & + & + & + & + & + \\
\hline ZT19 & + & + & + & + & + \\
\hline ZW22 & + & + & + & + & + \\
\hline ZL25 & + & + & + & + & + \\
\hline ZC36 & + & - & - & + & - \\
\hline ZB37 & + & - & + & - & + \\
\hline ZK41 & + & + & + & + & + \\
\hline ZJ42 & + & + & + & + & + \\
\hline ZK48 & + & + & + & + & + \\
\hline
\end{tabular}

+ Stands for production of biochemical, - stands for absence. 
Table 4. ZSB count in wheat rhizosphere under pot house conditions at different days after sowing.

\begin{tabular}{|c|c|c|c|}
\hline Treatments & \multicolumn{3}{|c|}{ ZSB Count in the rhizosphere $\left(X 10^{4} \mathrm{cfu} / \mathrm{gm}\right)$} \\
\hline Isolates & 30 DAS & 60 DAS & 90 DAS \\
\hline Control(uninoculated) & $3.667 \pm 0.0577^{\mathrm{e}}$ & $5.833 \pm 0.289^{\mathrm{f}}$ & $8.667 \pm 0.577^{c}$ \\
\hline 5 ppm Zn & $4.667 \pm 0.0577^{\mathrm{e}}$ & $7.500 \pm 0.500^{\mathrm{f}}$ & $10.333 \pm 0.577^{c}$ \\
\hline $5 \mathrm{ppm} \mathrm{Zn}$ as $\mathrm{ZnO}+\mathrm{ZA} 1$ & $9.333 \pm 1.1555^{\mathrm{bc}}$ & $20.000 \pm 1.000^{\mathrm{b}}$ & $30.333 \pm 0.577^{2}$ \\
\hline $5 \mathrm{ppm} \mathrm{Zn}$ as $\mathrm{ZnO}+\mathrm{ZJ} 3$ & $14.333 \pm 1.1555^{\mathrm{a}}$ & $23.000 \pm 2.646^{\mathrm{a}}$ & $31.667 \pm 1.528^{2}$ \\
\hline $5 \mathrm{ppm} \mathrm{Zn}$ as $\mathrm{ZnO}+\mathrm{ZM} 9$ & $6.667 \pm 0.5777^{\mathrm{d}}$ & $12.667 \pm 2.082^{\mathrm{de}}$ & $21.667 \pm 1.528^{b}$ \\
\hline $5 \mathrm{ppm} \mathrm{Zn}$ as $\mathrm{ZnO}+\mathrm{ZT} 19$ & $6.333 \pm 0.5777^{\mathrm{d}}$ & $13.000 \pm 1.000^{\mathrm{de}}$ & $21.667 \pm 0.577^{\mathrm{b}}$ \\
\hline $5 \mathrm{ppm} \mathrm{Zn}$ as $\mathrm{ZnO}+\mathrm{ZL} 25$ & $6.333 \pm 0.5777^{\mathrm{d}}$ & $11.333 \pm 0.577^{\mathrm{e}}$ & $23.667 \pm 0.577^{\mathrm{b}}$ \\
\hline $5 \mathrm{ppm} \mathrm{Zn}$ as $\mathrm{ZnO}+\mathrm{ZI} 4$ & $8.333 \pm 0.5777^{c}$ & $15.000 \pm 1.000^{\mathrm{cd}}$ & $22.667 \pm 2.887^{b}$ \\
\hline $5 \mathrm{ppm} \mathrm{Zn}$ as $\mathrm{ZnO}+\mathrm{ZK} 41$ & $10.333 \pm 2.517^{\mathrm{b}}$ & $17.667 \pm 2.517^{\mathrm{bc}}$ & $32.000 \pm 1.000^{2}$ \\
\hline $\mathrm{CD}$ at $5 \%$ & 1.5801 & 2.7745 & 2.1939 \\
\hline
\end{tabular}

The data represent mean \pm SD. Means with the same letter are not significantly different across the column. CD is calculated at $5 \%$ significance.

Table 5. Shoot biomass of wheat after different days of sowing (DAS) under pot conditions.

\begin{tabular}{|c|c|c|c|}
\hline Treatments & \multicolumn{3}{|c|}{ Shoot Biomass (mg/plant) } \\
\hline Isolates & 30 DAS & 60 DAS & 90 DAS \\
\hline Control (Uninoculated) & $83.333 \pm 7.024^{\mathrm{d}}$ & $312.000 \pm 19.079^{c}$ & $1319.000 \pm 110.729^{\mathrm{b}}$ \\
\hline 5 ppm Zn & $96.000 \pm 4.000^{\mathrm{cd}}$ & $354.000 \pm 56.045^{\mathrm{bc}}$ & $1324.000 \pm 305.005^{\mathrm{ab}}$ \\
\hline $5 \mathrm{ppm} \mathrm{Zn}$ as $\mathrm{ZnO}+\mathrm{ZA} 1$ & $112.000 \pm 9.165^{\mathrm{cdb}}$ & $445.000 \pm 16.093^{\mathrm{a}}$ & $1673.000 \pm 228.515^{a}$ \\
\hline $5 \mathrm{ppm} \mathrm{Zn}$ as $\mathrm{ZnO}+\mathrm{ZJ} 3$ & $136.000 \pm 15.716^{\mathrm{ab}}$ & $476.667 \pm 89.120^{\mathrm{a}}$ & $1690.000 \pm 325.447^{a}$ \\
\hline $5 \mathrm{ppm} \mathrm{Zn}$ as $\mathrm{ZnO}+\mathrm{ZM} 9$ & $120.000 \pm 14.422^{\mathrm{abc}}$ & $466.000 \pm 71.393^{\mathrm{a}}$ & $1675.000 \pm 225.000^{\mathrm{a}}$ \\
\hline $5 \mathrm{ppm} \mathrm{Zn}$ as $\mathrm{ZnO}+\mathrm{ZT} 19$ & $122.000 \pm 12.014^{\mathrm{abc}}$ & $357.000 \pm 51.856^{\mathrm{bc}}$ & $1665.000 \pm 403.129^{a}$ \\
\hline $5 \mathrm{ppm} \mathrm{Zn}$ as $\mathrm{ZnO}+\mathrm{ZL} 25$ & $126.000 \pm 4.000^{\mathrm{abc}}$ & $423.000 \pm 61.147^{\mathrm{ab}}$ & $1651.333 \pm 138.818^{\mathrm{ab}}$ \\
\hline $5 \mathrm{ppm} \mathrm{Zn}$ as $\mathrm{ZnO}+\mathrm{ZI} 4$ & $112.000 \pm 22.000^{\mathrm{cdb}}$ & $411.000 \pm 73.000^{\mathrm{a}}$ & $1664.000 \pm 39.000^{\mathrm{a}}$ \\
\hline $5 \mathrm{ppm} \mathrm{Zn}$ as $\mathrm{ZnO}+\mathrm{ZK} 41$ & $152.333 \pm 43.662^{\mathrm{a}}$ & $455.000 \pm 18.028^{\mathrm{ab}}$ & $1694.333 \pm 10.693^{\mathrm{a}}$ \\
\hline $\mathrm{CD}$ at $5 \%$ & 33.853 & 83.292 & 385.01 \\
\hline
\end{tabular}

The data represent mean \pm SD. Means with the same letter are not significantly different across the column. CD is calculated at $5 \%$ significance.

Table 6. Similarity index of isolates with the various bacterial species.

\begin{tabular}{cccc}
\hline $\begin{array}{c}\text { Bacterial } \\
\text { isolates }\end{array}$ & $\begin{array}{c}\text { Bacterial strains showing } \\
\text { maximum homology }\end{array}$ & $\begin{array}{c}\text { Similarity Index } \\
\mathbf{( \% )}\end{array}$ & Gen Bank accession No. \\
\hline ZA1 & Bacillus cereus CCM2010 & $99.2 \%$ & MW856664 \\
\hline ZJ3 & Psendomonas aeruginosa DSM50071 & $100 \%$ & MW856663 \\
\hline ZK41 & Bacillus tropicus MCCC1A01406 & $99.42 \%$ & MW856667 \\
\hline
\end{tabular}

\section{$16 S \mathrm{r} R \mathrm{~N}$ sequencing and phylogenetic tree}

On the basis of the effect on the shoot biomass and morphology, the three isolates were selected for gene sequencing. To identify the bacterial isolates, genomic DNA was isolated (Figure 2) and amplified using 27F and 1492R universal primers (Figure 3). 16S rDNA sequencing was done and phylogenetic tree was constructed. The data obtained from the NCBI GenBank database revealed a sequence similarity as depicted in Table 6. The isolates were found to be homologues to Bacillus cereus, Pseudomonas aeruginosa, Bacillus tropicus whose phylogenetic trees are shown in Figure 4, Figure 5, and Figure 6 respectively. 


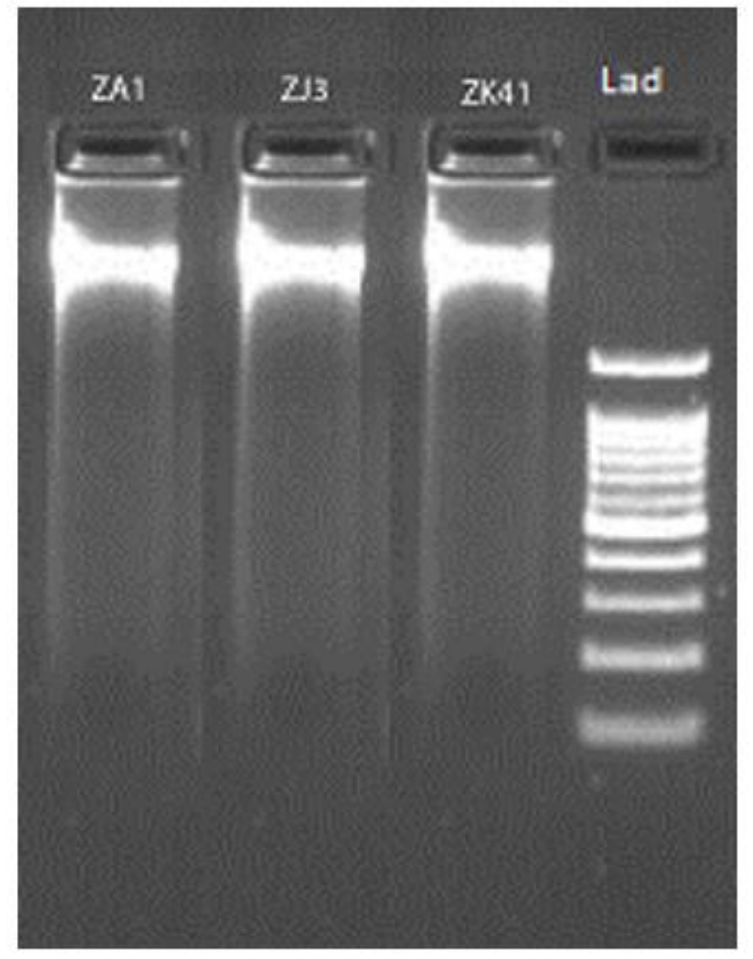

Figure 2. Genomic DNA of ZA1, ZJ3, ZK41, Lad-Ladder.

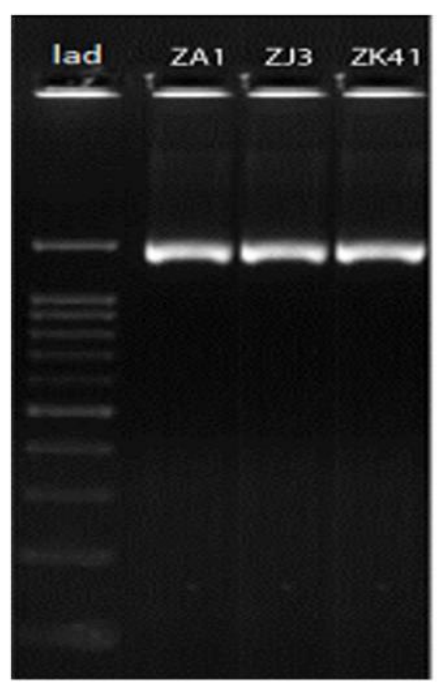

(a)

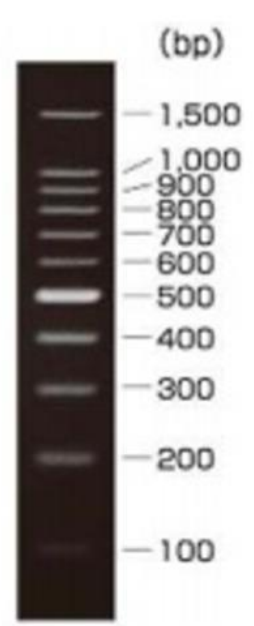

(b)
Figure 3. (a) PCR amplification of $16 \mathrm{~S}$ r-DNA fragment; the size of PCR amplified product is $\sim 1.5 \mathrm{~kb}$, (b) Ladder Specification.

\section{DISCUSSION}

$\mathrm{Zn}$ is a vital micronutrient that is required in minute quantities and it is indispensable for the growth of all forms of life. Humans and animals depend directly or indirectly upon plants for their growth. In context to this, it is imperative to know the status of the $\mathrm{Zn}$ in the soil. Many studies revealed that most of the Indian agricultural soils are deficient in $\mathrm{Zn}$. To accomplish the requirements of the crops, chemical fertilizers have been used extensively and nowadays it has become a very common practice to achieve desired results. But still, the amelioration of $\mathrm{Zn}$ deficiency remains the major concern as most of the applied $\mathrm{Zn}$ fertilizers $(60 \%)$ get converted to insoluble forms and hence no longer available to plants (Kamran et al., 2017). The Zn solubilising bacteria promote growth in plants via nutrient uptake, solubilisation of nutrients, nitrogen fixation and mineralization (Gouda et al., 2018). This can be attributed to many factors like the type of the soil, moisture content, presence of other nutrients etc. The main factors affecting $\mathrm{Zn}$ solubilisation is acidification through proton production, chemical transformation via redox reaction and chelating of siderophores (Costerousse et al., 2018).

In the present study $\mathrm{Zn}$ solubilising bacteria were isolated from the rhizospheric soil samples of wheat grown in Faridabad district by serial dilution and screened on B \& $\mathrm{R}$ media. Post 3 days incubation period colonies with clear halo zone were picked and solubilisation efficiency of the bacteria was determined. The results divulged that out of 50 isolates 8 displayed high $\mathrm{Zn}$ solubilisation efficiency. The halo zone diameter of these ranged from $0.8 \mathrm{~cm}$ to $2.8 \mathrm{~cm}$. Maximum solubilisation efficiency was displayed by (ZJ3) Pseudomonas aeruginosa (494\%), (ZK41) Bacillus tropicus (453\%) and (ZA1) Bacillus cereus (508\%). Mumtaz et al. (2017) showed that isolates displayed various $\mathrm{Zn}$ solubilisation efficiency (ZSE) that ranges from 123-296\% which corroborate the present data. In this study, various plant growth-promoting characteristics were studied and it was observed that most of the isolates have these traits. For example, all bacterial strains were tested positive for phosphate solubilisation efficiency (PSE) ranging from 150$550 \%$. The results are similar to the finding of Batool and Iqbal (2019) who reported quite similar findings concerning PSE.

The isolates were also checked for IAA synthesis and all strains have positive IAA synthesis following Mohite (2013) and Goswami 
et al. (2013) who reported that IAA a phytohormones present in plants stimulates root elongation and formation. Siderophores production was also tested and results revealed all isolates to be positive for the same. Siderophores assists in solubilisation and chelating of iron from its inactive form (Arora and Verma, 2017).
Siderophores chelates $\mathrm{Zn}$ and enhances its uptake (Pahari and Mishra, 2017). Ammonia production was also noted in all isolates except ZK7, ZK8, ZC36 and ZB38 and according to Agbodjato et al. (2015) production of ammonia indirectly affects plant growth thus it plays an important role.

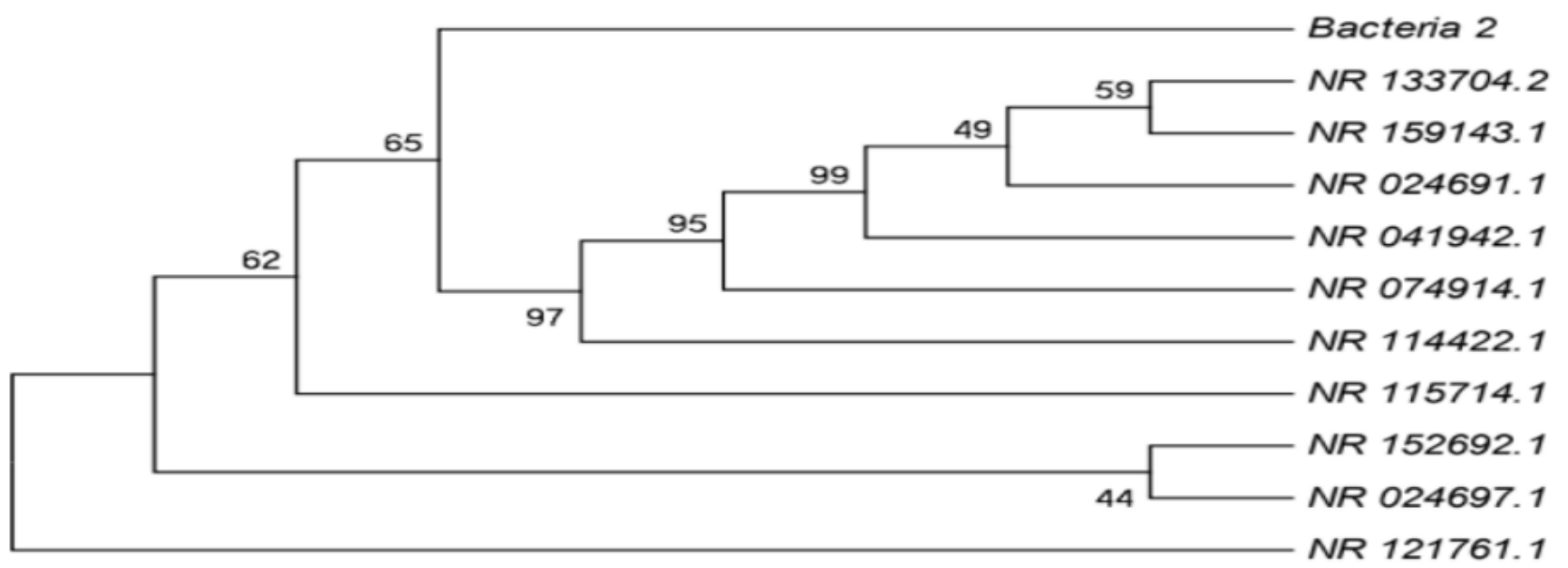

Figure 4. Phylogenetic analysis of ZA1 (bacteria 2) based on 16SrDNA sequence analysis. NR133704.2 (B. tianshenii YIM M13235); NR159143.1 (B. solisilvae NEAU-cbsb5); NR024691.1 (B. flexus IFO15715); NR041942.1 (B. acidicola 105-2 ); NR074914.1 (B. cytotoxicus NVH 391-98); NR114422.1 (B. psendomycoides); NR115714.1 (B. cereus CCM 2010); NR152692.1 (B. wiedmannii FSL W8-0169); NR121761.1 (B. toyonensis BCT-7112).

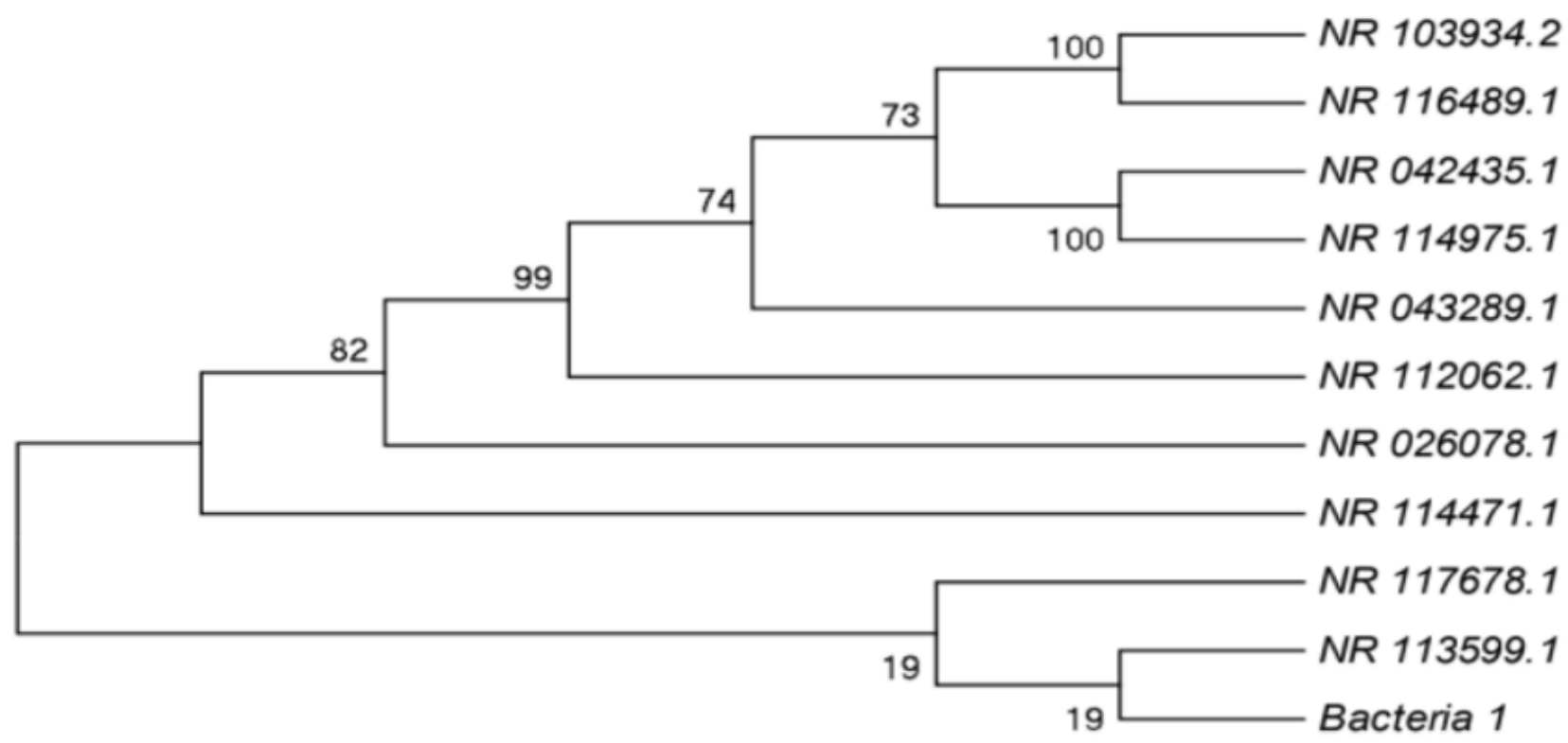

Figure 5. Phylogenetic analysis of ZJ3 (bacteria 1) based on 16SrDNA sequence analysis. NR103934.2 (P. stutzeri ATCC 17588); NR116489.1 (P stutzeri VKM B-975); NR042435.1 (P. nitroreducens IAM 1439); NR114975.1 (P. nitroreducens DSM14399); NR043289.1 (P. otitidis MCC10330); NR112062.1 (P. resinovorans ATCC 14235); NR026078.1 (P. aeruginosa DSM 50071); NR114471.1 (P. aeruginosa ATCC 10145); NR117678.1 (P. aeruginosa DSM 50071); NR113599.1 (P. aeruginosa NBRC 12689 16S). 


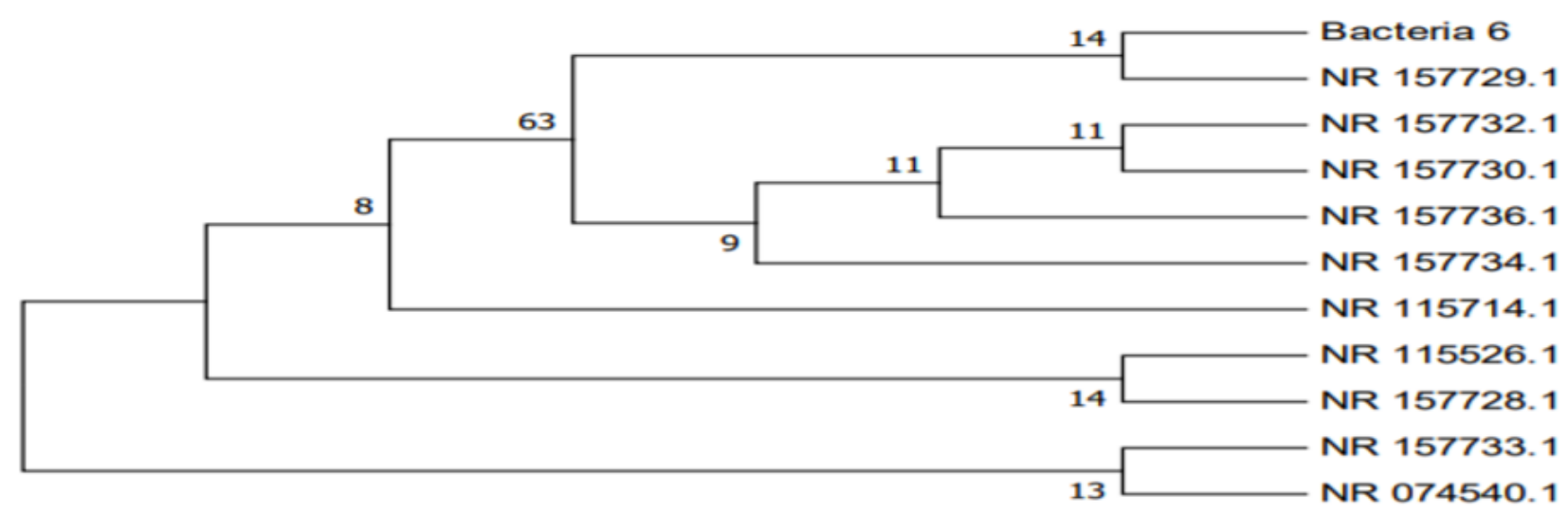

Figure 6. Phylogenetic analysis of ZK41 (bacteria 6) based on 16S rDNA sequence analysis. NR157729.1 (B. albus MCCC 1A02146); NR157732.1 (B. nitratireducens MCCC 1A00732); NR157730.1 (B. luti MCCC 1A00359); NR157736.1 (B. tropicus MCCC 1A01406); NR157734.1(B. paramycoides MCCC 1A04098); NR115714.1(B. cereus CCM 2010); NR115526.1 (B. cereus IAM 12605); NR157728.1(B. paranthracis MCCC 1A00395); NR157733.1(B. pacificus MCCC 1A06182); NR074540.1 (B. cereus ATCC 14579).

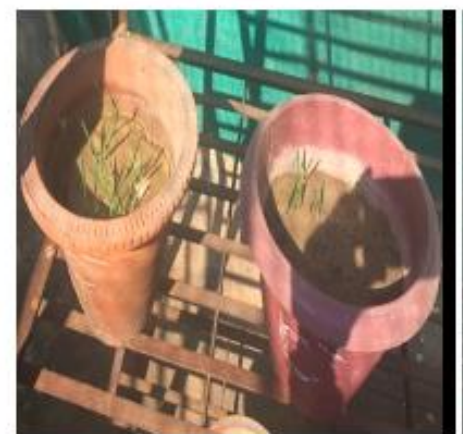

Control

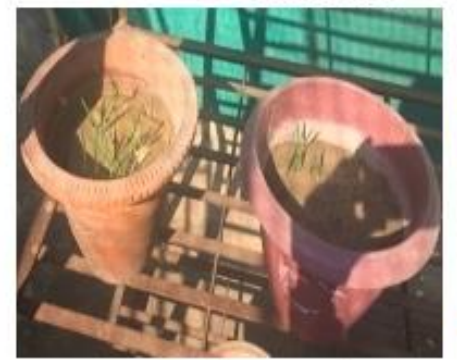

Control

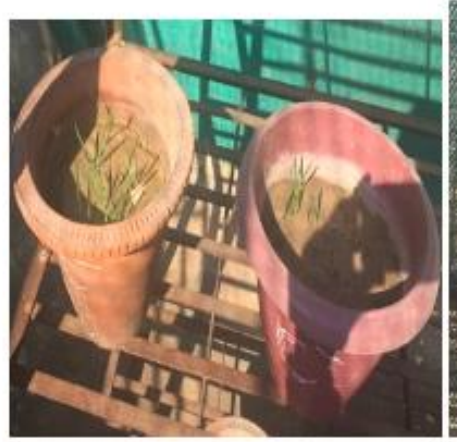

Control

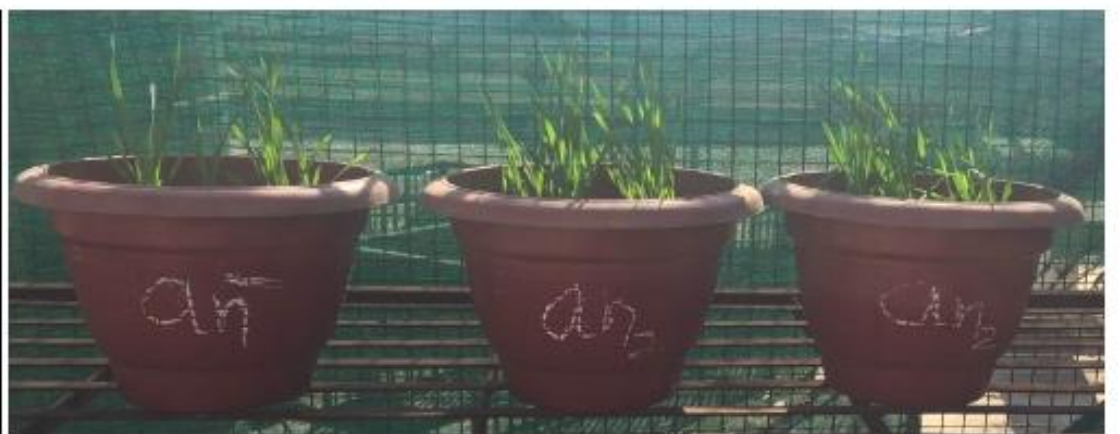

(a)

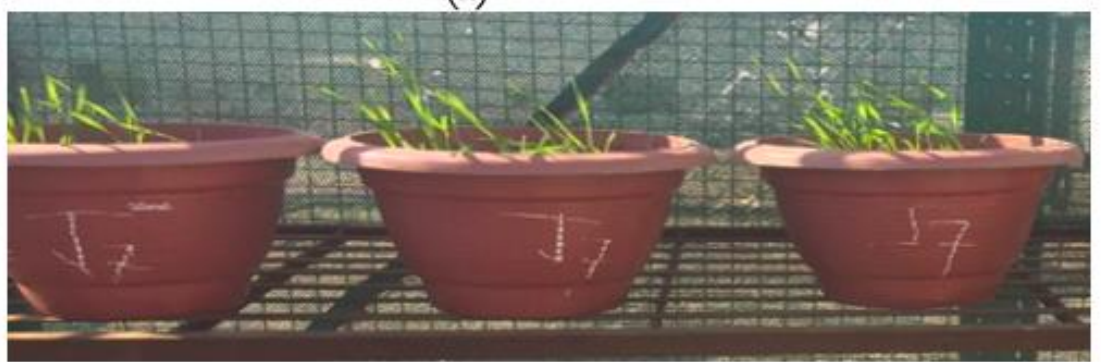

(b)

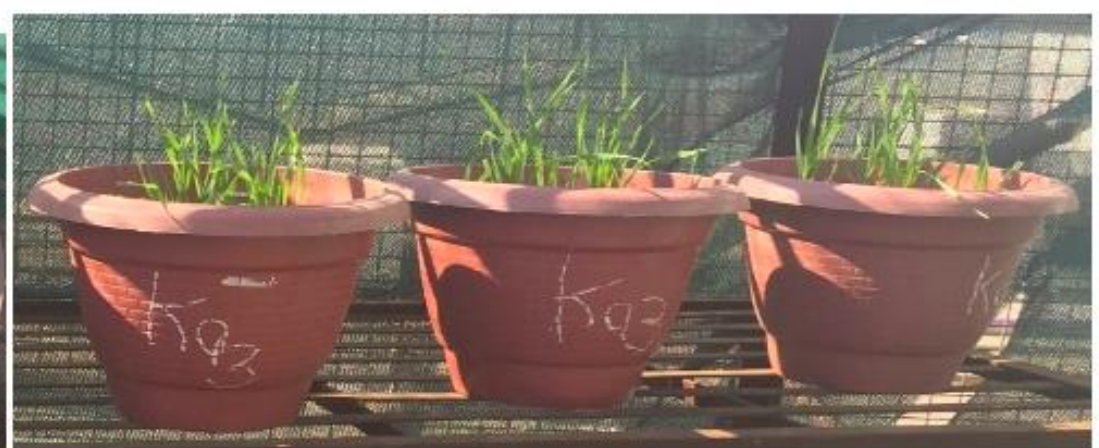

(c)

Figure 7. Growth of wheat inoculated with (a)ZA1, (b)ZJ3 and (c)ZK41 in comparison with control after 15 days of sowing. 
Another important attribute exhibited by plant growth promoting bacteria is production of EPS that plays an important role in the growth of bacteria. EPS is vital for balancing moisture content and growth during drought period. EPS forms a protective sheath around the rhizosphere root region thus shielding the plant root from invasion and desiccation. By improving soil structure and aggregation certain plants treated with EPS producing bacteria also displayed resistance to stress (Khan and Bano, 2019). EPS producing bacteria can even outlast under severe drought conditions as they can enhance the retention of water as well as monitor diffusion of organic carbon (Yadav et al., 2018).

All ZSB isolates survived and established well in wheat rhizosphere even after 90 DAS. The inoculation of isolates remarkably increased the growth of plants as evident by the shoot biomass calculated at various intervals. Plants treated with 5 ppm of $\mathrm{ZnO}$ displayed increased shoot biomass. The control had a mass of $1319 \mathrm{mg} / \mathrm{kg}$ post 90 days of inoculation and the rest of isolates showed greater mass than the control. The maximum shoot biomass of $1690 \mathrm{mg} / \mathrm{kg}$ was noted in ZJ3 and ZK41. ZA1 was found to be $99.2 \%$ similar to Bacillus cereus. ZJ3 shared $100 \%$ similarity to Pseudomonas aeruginosa while ZK41 showed 99.4\% similarity to Bacillus tropicus.

\section{CONCLUSION}

The results concluded that the isolates ZA1, ZJ3 and ZK41 possessing maximum homology with Bacillus cereus, Pseudomonas aeruginosa, and Bacillus tropicus, respectively can solubilise insoluble and inactive forms of $\mathrm{Zn}$ and thus ameliorate the growth of wheat crops. These isolates possess various PGPR characteristics like ammonia production, EPS production, IAA production, phosphate solubilisation, siderophores production, and chitinase activity that promote plant growth. The isolates can be thus used to boost the plant nutrient quality and yield and therefore help in eliminating $\mathrm{Zn}$ deficit. The isolated strains can be used as a potential bioinoculants. The current research provides data for future study on molecular pathways and mechanisms employed by these zinc solubilising bacteria.

\section{REFERENCES}

Abaid-Ullah, M., Nadeem, M., Hassan, M., Ganter, J., Muhammad, B., Nawaz, K., Shah, A. S., \& Hafeez, F. Y. 2015. Plant growth promoting rhizobacteria: an alternate way to improve yield and quality of wheat (Triticum aestivum). International Journal of Agriculture and Biology 17(1): 51-60.

Agbodjato, N. A., Amogou, O., Noumavo, P. A., Dagbénonbakin, G., Salami, H. A., Karimou, R., Alladé, A. M., Adedayo, O., Baba-Moussa, F., Adjanohoun, A., \& Baba-Moussa, L. S. 2015. Biofertilising, plant-stimulating and biocontrol potentials of maize plant growth promoting rhizobacteria isolated in central and northern Benin. African Journal of Microbiology Research 12(28):664-672.

Alloway, B. J. 2009. Soil factors associated with $\mathrm{Zn}$ deficiency in crops and humans. Environmental Geochemistry and Health 31(5): 537-548.

Arora, N. K. \& Verma, M. 2017. Modified microplate method for rapid and efficient estimation of siderophore produced by bacteria. 3 Biotech 7(6): 1-9.

Athokpam, H. S., Ralte, L., Chongtham, N., Singh, N. B., Devi, K. N., Singh, N. G., \& Sharma, P. T. 2018. Status and forms of $\mathrm{Zn}$ in acidic soils of Imphal West District, Manipur (India). International Journal of Current Microbiology and Applied Science 7(4): 2349-235.

Aznar, A. \& Dellagi, A. 2015. New insights into the role of siderophores as triggers of plant immunity: what can we learn from animals? Journal of Experimental Botany 66(11): 3001-3010.

Batool, S. \& Iqbal, A. 2019. Phosphate solubilizing rhizobacteria as alternative of chemical fertilizer for growth and yield of Triticum aestivum (Var. Galaxy 2013). Saudi Journal of Biological Sciences 26(7): 1400-1410.

Broadley, M. R., White, P. J., Hammond, J. P., Zelko, I., \& Lux, A. 2007. Zn in plants. New Phytologist 173(4): 677-702.

Cele, E. N. \& Maboeta, M. 2016. Response of soil enzyme activities to synergistic effects of biosolids and plants in iron ore mine soils. International Journal of Environmental Science and Technology 13(9): 2117-2126.

Costerousse, B., Schönholzer-Mauclaire, L., Frossard, E., \& Thonar, C. 2018. Identification of heterotrophic $\mathrm{Zn}$ mobilization processes among bacterial strains isolated from wheat rhizosphere (Triticum aestivum L.). Applied and Environmental Microbiology 84(1): e01715-17.

Crowley, D. E. 2006. Microbial siderophores in the plant rhizosphere. In Iron nutrition in plants and rhizospheric microorganisms pp. 169-198. Springer, Dordrecht.

El-Sayed, W. S., Akhkha, A., El-Naggar, M. Y., \& Elbadry, M. 2014. In vitro antagonistic activity, plant growth promoting traits and phylogenetic affiliation of rhizobacteria associated with wild plants grown in arid soil. Frontiers in Microbiology 5: 651.

Goswami, D., Vaghela, H., Parmar, S., Dhandhukia, P., \& Thakker, J. N. 2013. Plant growth promoting potentials of Pseudomonas spp. strain OG isolated from marine water. Journal of Plant Interactions 8(4): 281-290.

Goteti, P. K., Emmanuel, L. D. A., Desai, S., \& Shaik, M. H. A. 2013. Prospective $\mathrm{Zn}$ solubilising bacteria for enhanced nutrient uptake and growth promotion in maize (Zea mays L.). International Journal of Microbiology 2013: 1-7. 
Gouda, S., Kerry, R. G., Das, G., Paramithiotis, S., Shin, H. S., \& Patra, J. K. 2018. Revitalization of plant growth promoting rhizobacteria for sustainable development in agriculture. Microbiological Research 206: 131-140.

Hafeez, F. Y., Abaid-Ullah, M., \& Hassan, M. N. 2013. Plant growth-promoting rhizobacteria as $\mathrm{Zn}$ mobilizers: a promising approach for cereals biofortification. In Bacteria in Agrobiology: Crop Productivity .pp. 217-235. Springer, Berlin, Heidelberg.

Hina, J., Akhtar, M. J., Asghar, H. N., \& Amer, J. 2018. Screening of $\mathrm{Zn}$ solubilizing bacteria and their potential to increase grain concentration in wheat (Triticum aestivum). International Journal of Agriculture and Biology 20(3): 547-553.

Kamran, S., Shahid, I., Baig, D. N., Rizwan, M., Malik, K. A., \& Mehnaz, S. 2017. Contribution of Zn solubilizing bacteria in growth promotion and $\mathrm{Zn}$ content of wheat. Frontiers in Microbiology 8(2017): 2593.

Kour, R., Jain, D., Bhojiya, A. A., Sukhwal, A., Sanadhya, S., Saheewala, H., Jat, G., Singh, A. \& Mohanty, S. R., 2019. Zn biosorption, biochemical and molecular characterization of plant growth-promoting Zn-tolerant bacteria. 3 Biotech 9(11): 1-17.

Kaushal, M., Mandyal, P., \& Kaushal, R. 2019. Field based assessment of Capsicum annuum performance with inoculation of rhizobacterial consortia. Microorganisms 7(3): 89.

Khan, N. \& Bano, A. 2019. Exopolysaccharide producing rhizobacteria and their impact on growth and drought tolerance of wheat grown under rainfed conditions. PLoS One 14(9): e0222302.

Khanghahi, M. Y., Ricciuti, P., Allegretta, I., Terzano, R., \& Crecchio, C. 2018. Solubilization of insoluble $\mathrm{Zn}$ compounds by $\mathrm{Zn}$ solubilizing bacteria (ZSB) and optimization of their growth conditions. Environmental Science and Pollution Research 25(26): 25862-25868.

Kuan, K. B., Othman, R., Abdul Rahim, K., \& Shamsuddin, Z. H. 2016. Plant growth-promoting rhizobacteria inoculation to enhance vegetative growth, nitrogen fixation and nitrogen remobilisation of maize under greenhouse conditions. PloS One 11(3): e0152478.

Kumar, S., Stecher, G., \& Tamura, K., 2016. MEGA7: Molecular evolutionary genetics analysis version 7.0 for bigger datasets. Molecular Biology and Evolution 33(7): 1870-1874.

Malik, R. S., Yadav, H. K., Narender, R., \& Sangwan, P. 2017. Background levels of $\mathrm{Zn}$, iron, manganese and copper in soil series of Haryana and their relationship with soil properties. Indian Journal of Agricultural Sciences 87(8): 10941098.

Mohite, B. 2013. Isolation and characterization of indole acetic acid (IAA) producing bacteria from rhizospheric soil and its effect on plant growth. Journal of Soil Science and Plant Nutrition 13(3): 638-649.

Moustaine, M., Elkahkahi, R., Benbouazza, A., Benkirane, R., \& Achbani, E. H. 2017. Effect of plant growth promoting rhizobacterial (PGPR) inoculation on growth in tomato (Solanum lycopersicum L.) and characterization for direct PGP abilities in Morocco. International Journal of Environment, Agriculture and Biotechnology 2(2): 590-596.

Mumtaz, M. Z., Ahmad, M., Jamil, M., \& Hussain, T. 2017. Zn solubilizing Bacillus spp. potential candidates for biofortification in maize. Microbiological Research 202(2017):51-60.

Noulas, C., Tziouvalekas, M., \& Karyotis, T. 2018. Zn in soils, water and food crops. Journal of Trace Elements in Medicine and Biology 49: 252-260.

Pahari, A. \& Mishra, B. B. 2017. Characterization of siderophore producing Rhizobacteria and Its effect on growth performance of different vegetables. International Journal of Current Microbiology and Applied Sciences 6(5): 1398-1405.

Pahari, A., Pradhan, A., Nayak, S. K., \& Mishra, B. B. 2017. Bacterial siderophore as a plant growth promoter. In Microbial Biotechnology. pp. 163-180. Springer, Singapore. Pande, A., Pandey, P., Mehra, S., Singh, M., \& Kaushik, S. 2017. Phenotypic and genotypic characterization of phosphate solubilizing bacteria and their efficiency on the growth of maize. Journal of Genetic Engineering and Biotechnology 15(2): 379-391.

Prasad, R., Kumar, M., \& Varma, A. 2015. Role of PGPR in soil fertility and plant health. In Plant-growth-promoting rhizobacteria (PGPR) and medicinal plants .pp. 247-260. Springer, Cham.

Roohani, N., Hurrell, R., Kelishadi, R., \& Schulin, R. 2013. Zn and its importance for human health: An integrative review. Journal of Research in Medical Sciences: The Official Journal of Isfahan University of Medical Sciences 18(2): 144-157.

Saravanan, V. S., Subramoniam, S. R., \& Raj, S. A. 2004. Assessing in vitro solubilization potential of different $\mathrm{Zn}$ solubilizing bacterial (ZSB) isolates. Brazilian Journal of Microbiology 35(12): 121-125.

Sharma, A., Patni, B., Shankhdhar, D., \& Shankhdhar, S. C. 2013. $\mathrm{Zn}$-an indispensable micronutrient. Physiology and Molecular Biology of Plants 19(1): 11-20.

Upadhyay, S. K., Singh, J. S., \& Singh, D. P. 2011. Exopolysaccharide-producing plant growth-promoting rhizobacteria under salinity condition. Pedosphere 21(2): 214222.

Vejan, P., Abdullah, R., Khadiran, T., Ismail, S., \& Nasrulhaq Boyce, A. 2016. Role of plant growth promoting rhizobacteria in agricultural sustainability-a review. Molecules 21(5): 573.

Vidyashree, N. D. 2016. Isolation and characterization of $\mathrm{Zn}$ solubilizing bacteria from stone quarry dust powder. International Journal of Agriculture Sciences: 0975-3710.

Yadav, A. N. \& Yadav, N., 2018. Stress-adaptive microbes for plant growth promotion and alleviation of drought stress in plants. Acta Scientific Agriculture 2(6): 85-88.

Zhao, Y., Shi, R., Bian, X., Zhou, C., Zhao, Y., Zhang, S., ... \& Zhang, T. 2019. Ammonia detection methods in photocatalytic and electrocatalytic experiments: how to improve the reliability of $\mathrm{NH} 3$ production rates? Advanced Science 6(8): 1802109. 